\title{
Differentiation of flea communities of small mammals in selected habitats in the Eastern Tatra Mts
}

\author{
Ivan Balážz, Filip Tulis, Martina Zigová \\ Department of Ecology and Environmental Sciences, Faculty of Natural Sciences, Constantine the Philosopher \\ University in Nitra, Trieda A. Hlinku 1, 94974 Nitra, Slovak Republic
}

\begin{abstract}
BalÁž, I., Tulis, F., Zigová, M., 2019. Differentiation of flea communities of small mammals in selected habitats in the Eastern Tatra Mts. Folia Oecologica, 46: 137-145.

Research into small mammals and their ectoparasites was carried out in the Belianske Tatras during 2010-14, evaluating flea communities found on small mammals on the basis of species richness, abundance and level of infestation. Flea infestation of host species occurred mostly in C. glareolus with the highest infestation rates recorded in $S$. alpinus, the earlier mentioned $C$. glareolus, $N$. anomalus and $N$. fodiens. Based on their prevalence in all the examined hosts, the most frequent flea communities found were M. turbidus, C. agyrtes, A. penicilliger and $P$. soricis. In addition, flea prevalence in all the captured host species was evaluated. The most frequent flea communities were $M$. turbidus, $P$. soricis and $D$. dasycnema ( 8 host species); C. agyrtes and H. orientalis (7); A. penicilliger and P. bidentata (4); C. uncinatus, P. sylvatica and R. integela (3); and $M$. rectangulatus, $N$. fasciatus and $C$. bisoctodentatus (2), while $A$. nuperus and $A$. arvicolae were recorded in only one host species.
\end{abstract}

\section{Keywords}

Eulipotyphla, Rodentia, Siphonaptera, Tatra Mountains

\section{Introduction}

Many factors affect the diversity of parasites appearing in host species. The study of parasite biodiversity, in contrast to free-living organisms, covers the phenomenon of "dual location". The first location for parasites is the body of its host, while the second is characterised by the geographical location of the host species and consequently the presence of its parasite. Thus, the structure of flea appearance within its host species is also affected by environmental conditions at a local scale (KRASNOv, 2008). Since no similarly focused research had ever been conducted in Slovakia and particularly at the High Tatra Mountains, nothing has been published yet, even though research into the appearance of small mammals and blood-sucking fleas on them along the slopes of the Belianske Tatras was conducted in 2010-14. The first ever study of fleas on small mammals in the High Tatra region was published by JORDAN (1932), while fleas on small mammals in the High Tatras and the Belianske Tatras were studied by RosickÝ $(1955,1974)$, and parasite fauna was evaluated from the zoogeografical perspective by MrCiaK and RosickÝ $(1970,1975)$ and by RosickÝ and MrCiaK (1970). Subsequently, fleas found on small mammals native to the High Tatras were the subject of studies conducted by JURÍK (1955), CYPRICH and KIEFER (1972), TrPiš (1994), Dudich $(1996,1997)$ and CYPrICH and ŠTiaVnickÁ (2003). RosickÝ (1950, 1952), JuRíK (1968), BartKowSKa (1973), Dudich $(1982,1989)$, Dudich and MATOUŠEK (1985) focused their research on fleas that had colonised small mammals in the Western Tatras. This pa-

*Corresponding author: e-mail: ibalaz@ukf.sk 
per aims is to evaluate flea communities on small mammals in the Eastern Tatra Mountains based on species richness, abundance and small mammal infestation.

\section{Materials and methods}

\section{Study area}

The Belianske Tatras are situated in the northern part of Slovakia, between $49^{\circ} 11^{\prime}$ and $49^{\circ} 17^{\prime}$ North latitude and $20^{\circ} 08^{\prime}$ and $20^{\circ} 19^{\prime}$ East longitude. They form a 14-kilometre-long limestone ridge stretching east to west and lying almost perpendicular to the main ridge of the High Tatras (MIDRIAK, 1983). The Belianske Tatras are among the highest carbonate mountains in the Western Carpathians. The entire mountain range covers an area of 64 square kilometres (KANKA, 2008). The mountain massif is composed of limestone and dolomite, with a distinct karst topography which is fundamentally different from the predominant granite and slate High Tatras. The only cave in the Tatra Mountains accessible to the public - Belianska Cave - is located there. The Belianske Tatras are part of Tatra National Park. The mountain range (montan) has a typical forest elevation of 700 (800) to 1,380 metres. The Belianske Tatras' mixed forests are composed of maple spruce, beech spruce and beech firs. In addition to the mixed fir-beech-spruce stands (at Javorina), there are mixed stands with wych elm (Ulmus glabra). The rich vegetation cover is complemented by large-leaved linden (Tilia platyphyllos) and sea-buckthorn (Sorbus aria). The subalpine forest which follows the mountain contour and ends with the upper forest boundary at 1,800 metres above sea level is covered with Pinus mugo pumilio and other vegetation. Limb pine (Pinus cembra) also extends into this zone. Knee timber vegetation has been decimated in the past mainly due to clearing for pastures; consequently secondary subalpine meadows with very rich plant life have emerged, ranking among the most resplendent and beautiful habitats for Western Carpathian species.

\section{Collecting the fleas}

At the Belianske Tatras in north central Slovakia, small mammals and their blood ectoparasites were researched over three seasons (spring, summer and autumn) during 2010-14. They were captured at nine locations in the eastern Tatra Mountains (Fig. 1), with trapping sites set at elevations along the slopes ranging from 914 to 1,654 metres. The trap sites were situated within four habitat types: 1) Mountain hay meadows, 2) Ruderal communities, 3) Spruce and mixed spruce and 4) Rock slope. They were defined in the Catalogue of habitats of Slovakia (STANoví and VALACHOVIČ, 2002), which was prepared according to Council Directive 92/43/EEC - the "Habitat Directive". Live traps were used for CMR (Capture-Mark-Recapture) ecological surveying of the small animals. The traps were set over 2-4 trapping days, mostly in lines (50 traps for each line) at Locations 1 and 3 and arranged in grids of five by ten traps. They were checked twice a day. Bait was made from a mixture of cereals, apples and mealworms.

Fleas collected from the small mammals trapped were recorded and preserved in $70 \%$ ethyl alcohol, with some of the specimens mounted on slides. O'Mahony's method (RosickÝ, 1957) was used to process and mount the fleas in Canada balm on the microscope slides. The flea species were identified using keys developed by RosickÝ (1957), Skuratowicz (1967), Brinck-LindRoth and SMit (2007). The structural and quantitative characteristics of the flea communities found on the small mammals were assessed and the data was analysed by using the dominance and prevalence on all small mammal individuals and the prevalence on small mammal species developed by SCHWERDTFEger (1975) and MARgolis et al. (1982). Ecological indices of dominance $(\mathrm{D} \%)$, prevalence $(\mathrm{P} \%)$, mean intensity of infestation (MII), ratio of host individual

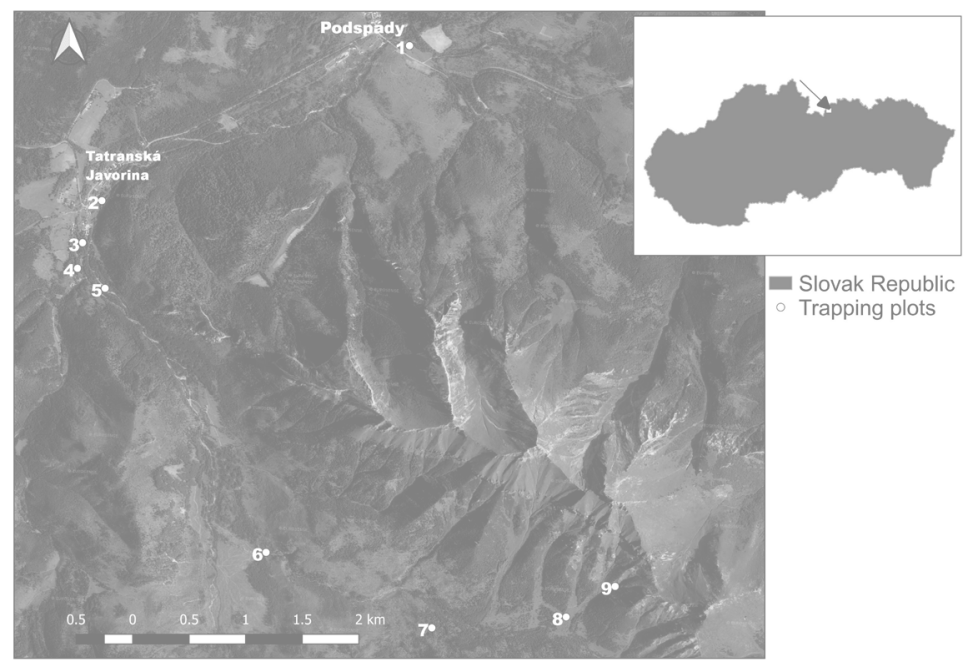

Fig. 1. Trapping sites in the Eastern Tatras of small mammals hosting fleas. 
infested (BUSH et al., 1997) and the preference index (Ip) (DuDICH, 1995) were calculated where $\mathrm{P} \%$ is the number of individual host species infested with a particular parasite species/number of hosts examined, Nhspi is the number of host species infested with a particular flea species, MII is the total number of parasites of a particular species found in a sample divided by the number of hosts infested with that parasite and the preference index (Ip) is the rate of a parasite bond to a particular host species. At Location 4, we determined 14 flea species due to the stationary capture of small mammals during the five research years. This site was evaluated separately.

\section{Results}

In total, 1,969 specimen of fleas belonging to 15 species and three families (Ceratophyllidae, Ctenophthalmidae and Hystrichopsyllidae) were collected from small mammal hosts. In the five research years running from 2010 to 2014, a total of 342 individuals from 16 species of small mammals were captured (Table 1): Amalaraeus arvicolae (Ioff, 1948); Amalaraeus penicilliger (Grube, 1851); Atyphloceras nuperus (Jordan, 1931); Ctenophthalmus agyrtes (Heller, 1896); Ctenophthalmus bisoctodentatus Kolenati, 1863; Ctenophthalmus uncinatus (Wagner, 1898); Doratopsylla dasycnema (Rothschild, 1897); Hystrichopsylla orientalis (Smit, 1956); Megabothris rectangulatus (Wahlgren, 1903); Megabothris turbidus (Rothschild, 1909); Nosopsyllus fasciatus (Bosc d'Antic, 1800); Palaeopsylla soricis (Dale, 1878); Peromyscopsylla bidentata (Kolenati, 1863); Peromyscopsylla silvati- ca (Meinert, 1896); Rhadinopsylla integella (Jordan and Rothschild, 1921). The highest dominance was recorded in C. agyrtes (26.1\%), M. turbidus (25.8\%), A. penicilliger (18.9\%) and P. soricis (10.1\%). No dominance values exceeded $10 \%$ in the rest of the species that were trapped

Based on their prevalence on all the examined individual hosts (Table 1), the most frequent flea species found were M. turbidus (12.74\%), C. agyrtes (10.37\%), A. penicilliger $(8.22 \%)$ and $P$. soricis $(3.56 \%)$. We also evaluated prevalence on all the captured host species. The most frequent were $M$. turbidus, $P$. soricis and D. dasycnema $(50 \%$ occurring on eight host species); then $C$. agyrtes and $H$. orientalis (43.8\% on seven host species); A. penicilliger and $P$. bidentata (25\% on four species); $C$. uncinatus, $P$. silvatica and $R$. integela (18.8\% on 3 species); M. rectangulatus, $N$. fasciatus and C. bisoctodentatus $(12.5 \%$ on two species). A. nuperus and A. arvicolae were recorded only on one host species $(6.3 \%)$ (see Table 1$)$. The host spectrum was represented by 16 captured small mammal species, but only 11 species were tested positive for occurrence of fleas (Table 2). The most infested host species out of all the individuals was $C$. glareolus (16.6\%). An increased percentage was found in Apodemus flavicollis $(5.6 \%)$ and Sorex araeus (3.2\%). 27.9\% of all the examined host individuals were positive for flea occurrence (612 specimens were infested out of the 2,190 examined small mammals, including recaptured individuals). In the case of the host species, the highest infestation was recorded in S. alpinus $(52.9 \%$ of all the specimens were positive), C. glareolus (33.8\%), N. anomalus $(33.3 \%)$ and $N$. fodiens $(31.1 \%)$. No infestation in the rest of the examined host species exceeded $30 \%$ (Table 2).

Table 1. Quantitative structure of fleas from small mammals in the Belianske Tatras (2010-2014)

\begin{tabular}{crrrrr}
\hline Fleas & $\mathrm{N}$ & $\mathrm{D}(\%)$ & $\mathrm{P}(\%)$ & Nhspi & MII \\
\hline Amalaraeus arvicolae & 1 & 0.05 & 0.05 & 1 & 1.00 \\
Amalaraeus penicilliger & 374 & 18.99 & 8.22 & 4 & 2.08 \\
Atyphloceras nuperus & 3 & 0.15 & 0.14 & 1 & 1.00 \\
Ctenophthalmus agyrtes & 514 & 26.10 & 10.37 & 7 & 2.26 \\
Ctenophthalmus bisoctodentatus & 4 & 0.20 & 0.18 & 2 & 1.00 \\
Ctenophthalmus uncinatus & 92 & 4.67 & 2.88 & 3 & 1.46 \\
Doratopsylla dasycnema & 91 & 4.62 & 2.79 & 8 & 1.49 \\
Hystrichopsylla orientalis & 47 & 2.39 & 1.64 & 7 & 1.31 \\
Megabothris rectangulatus & 9 & 0.46 & 0.27 & 2 & 1.50 \\
Megabothris turbidus & 509 & 25.85 & 12.74 & 8 & 1.82 \\
Nosopsyllus fasciatus & 7 & 0.36 & 0.23 & 2 & 1.17 \\
Palaeopsylla soricis & 198 & 10.06 & 3.56 & 8 & 2.54 \\
Peromyscopsylla bidentata & 69 & 3.50 & 2.19 & 4 & 1.44 \\
Peromyscopsylla silvatica & 39 & 1.98 & 1.37 & 3 & 1.30 \\
Rhadinopsylla integella & 12 & 0.61 & 0.50 & 3 & 1.09 \\
\hline Total & 1969 & 100 & - & 11 & - \\
\hline
\end{tabular}

$\mathrm{N}$, abundance of fleas; D\%, dominance; $\mathrm{P} \%$, prevalence; Nhspi, number of host species infested with particular flea species; MII, mean intensity of infestation. 
Table 2. Prevalence of fleas of small mammals in the Belianska Tatras in the years 2010-2014

\begin{tabular}{ccccc}
\hline Host & NInf & NEx & \%isp & \%iex \\
\hline Apodemus flavicollis & 123 & 445 & 27.6 & 5.6 \\
Apodemus sylvaticus & 0 & 4 & 0.0 & 0.0 \\
Apodemus uralensis & 0 & 2 & 0.0 & 0.0 \\
Clethrionomys glareolus & 363 & 1,073 & 33.8 & 16.6 \\
Chionomys nivalis & 0 & 84 & 0.0 & 0.0 \\
Microtus agrestis & 10 & 36 & 27.8 & 0.5 \\
Microtus arvalis & 2 & 10 & 11.1 & 0.1 \\
Microtus subterraneus & 1 & 9 & 12.2 & 0.0 \\
Microtus tatricus & 9 & 74 & 0.0 & 0.4 \\
Sicista betulina & 0 & 1 & 0.0 & 0.0 \\
Crocidura suaveolens & 0 & 33.3 & 0.0 \\
Neomys anomalus & 2 & 6 & 31.1 & 0.1 \\
Neomys fodiens & 14 & 45 & 52.9 & 0.6 \\
Sorex alpinus & 9 & 17 & 21.8 & 0.4 \\
Sorex araneus & 71 & 326 & 14.5 & 3.2 \\
Sorex minutus & 8 & 55 & 27.9 & 0.4 \\
\hline Total & 612 & 2,190 & \\
\hline
\end{tabular}

$\mathrm{N}$, number of marked individuals of particular mammals species; NInf, number of positive findings of fleas on small mammals; NEx, number of examined specimens of small mammals; \%isp, number of individuals of particular infested host species / number of individuals of a particular examined host species $\times 100 ; \% \mathrm{iex}-$ number of individuals of particular infested host species / number of all examined host individuals $\times 100$.

Table 3. Overview of fleas from small mammals in the Belianske Tatras (2010-2014)

\begin{tabular}{ccccccccccccc}
\hline Flea sp. / Host sp. & Mar & Afl & Cgl & Mag & Msu & Mta & Nan & Nfo & Sal & Sar & Smi & $\mathrm{n}$ \\
\hline A. arvicolae & - & - & - & - & - & 1 & - & - & - & - & - & 1 \\
A. penicilliger & - & 6 & 364 & 3 & - & - & - & - & 1 & - & - & 374 \\
A. nuperus & - & - & 3 & - & & - & - & - & - & - & - & 3 \\
C. agyrtes & 1 & 127 & 358 & 19 & - & 2 & - & - & - & 5 & 2 & 514 \\
C. bisoctodentatus & - & 1 & 3 & - & - & - & - & - & - & - & - & 4 \\
C. uncinatus & - & 7 & 84 & - & - & - & - & - & - & 1 & - & 92 \\
D. dasycnema & - & 4 & 3 & 1 & - & - & 1 & 3 & 8 & 66 & 5 & 91 \\
H. orientalis & - & 5 & 21 & 6 & - & 1 & - & 2 & 2 & 10 & - & 47 \\
M. rectangulatus & - & - & 8 & - & - & 1 & - & - & - & - & - & 9 \\
M. turbidus & 2 & 155 & 337 & 10 & - & 2 & 1 & - & - & 1 & 1 & 509 \\
N. fasciatus & - & 5 & 2 & - & - & - & - & - & - & - & - & 7 \\
P. soricis & - & 3 & 9 & - & 1 & - & 2 & 17 & 22 & 138 & 6 & 198 \\
P. bidentata & - & 4 & 63 & - & - & 1 & - & - & - & - & 1 & 69 \\
P. silvatica & - & - & 34 & - & - & 4 & - & - & - & 1 & - & 39 \\
R. integella & - & 5 & 6 & - & - & 1 & - & - & - & - & - & 12 \\
\hline Total & 3 & 322 & 1,295 & 39 & 1 & 13 & 4 & 22 & 33 & 222 & 15 & 1,969
\end{tabular}

Mar, Microtus arvalis; Afl, Apodemus flavicollis; Cgl, Clethrionomys glareolus; Mag, Microtus agrestis; Msu, Microtus subterraneus; Mta, Microtus tatricus; Nan, Neomys anomalus; Nfo, Neomys fodiens; Sal, Sorex alpinus; Sar, Sorex araneus; Smi, Sorex minutus; $\mathrm{n}$, abundance of fleas. 


\section{Overview of flea species by hosts}

Individual host species were infested by different flea species, varying in intensity. The greatest number, as well as species richness of fleas, was found in Apodemus flavicollis, Clethrionomys glareolus and Sorex araneus. In the case of $C$. glareolus, all flea species identified in the community of small terrestrial mammals of the examined area (Table 3) were recorded with the exception of one species: A. arvicolae.

\section{Review of flea species}

Hystrichopsylla orientalis (Smit, 1956) is a euryzonal and euryxenous species widespread in Eastern and Southeastern Europe, extending across the Polish plain to Germany through the Panónska Basin to the Alps. It is present everywhere in Slovakia, with $H$. talpae ranging into the western and central regions of the country, so both species often occur together. The species is widespread throughout the Tatras and in the Tatra basins. On the other hand, $H$. orientalis is a mesochronous species which can be found only during a short period of the year (July-October), usually in the coats of a wide range of hosts. H. orientalis prefers $C$. glareolus and $S$. araneus, but the main host of this flea species is Apodemus agrarius.

Atyphloceras nuperus (Jordan, 1931) is a monoxenous, stenochronic and strictly zonal species which lives almost exclusively on $C$. glareolus at the montane level of European mountains such as the Pyrenees, Alps, Carpathians, Balkans and Caucasus. These are flea species that thrive among fauna that live in mountainous areas In Slovakia, it occurs almost exclusively in the mountains where Abies alba naturally occur.

Ctenophthalmus bisoctodentatus (Kolenati, 1863) is a specific parasite of Talpa europaea which penetrates with this mole species above the knee timber level. Our experience confirms that other small mammal species use mole corridors for subterranean movement as well.

Ctenophthalmus agyrtes (Heller, 1896) is a polysonal pleioxenous parasite found primarily on small mammals living in forest geobiocoenoses. It was the most widely represented species collected by us in all vegetation zones. The range is part of the subspecies introgression/subspecies $C$. a. kleinschmidtianus $\times$ C. a. peusianus, similar to observations in the Belianske Tatras of Poland. (BARTKOWSKA, 1973). It has a broad host spectrum and occurs throughout the year. C. agyrtes prefers C. glareolus and A. flavicollis.

Ctenophthalmus uncinatus (Wagner, 1898) is a boreomontaneous species spread in the mountainous areas of Central Slovakia. In the conditions found in the Carpathian mountain range, it is an exclusively mountain species and is well documented with a number of sites located within the Belianske Tatras. The first occurrence of the species in the High Tatras was documented in Tatranská Lomnica (RosICKÝ, 1950), while its occurrence around Javorina and Žiar was confirmed by Cyprich and Kiefer (1972). Popu- lations of the species at the Carpathian range in Slovakia belong to the nominotypic subspecies of $C$. u. uncinatus (Dudich, 2004). This flea species prefers $C$. glareolus.

Doratopsylla dasycnema (Rothschild, 1897) is a pleioxenous species which parasitises Soricidae insectivores in forest habitats. The genetic influence of the eastern subspecies $D . d$. cuspis has reached the Belianske Tatras.

Palaeopsylla soricis (Dale, 1878) is a polysonal pleioxenous parasite of insectivores with wide ecological valence. The genetic influence of the eastern subspecies $P$. $s$. starki has reached the Belianske Tatras.

Rhadinopsylla integella (Jordan and Rothschild, 1921) is a boreomontane species ranging from the uplands to the subalpine zone. It is a stenochtonous species which belongs to the permanent winter sifonaptera elements of C. glareolus.

Peromyscopsylla bidentata (Kolenati, 1863) is a polysonal pleioxenous, winter type of small mammal siphonaptera group whose main host is $C$. glareolus. It also parasites voles of the Microtus and Arvicola genus. This species has an almost continuous distribution in forest geobiocoenoses from hilly to supramontaneous levels. Currently, Dudich (1996) qualifies the bizonal character of the species distribution as a secondary, anthropically determined phenomenon.

Peromyscopsylla silvatica (Meinert, 1896) is a boreomontaneous species which is a geographic vicariant of $P$. fallax (parapatric type of species distribution, DUDICH (1997). P. silvatica is a monotypical species which parasitises the species of Clethrionomys, Microtus and Arvicola.

Amalaraeus arvicolae (Ioff, 1948) is a eurosiberian species occurring in Central Europe, particularly in mountainous areas. It is prevalent throughout the year, especially during the winter. The main host is M. subterraneus, but it has also been found on M. tatricus.

Amalaraeus penicilliger (Grube, 1851) is a pleioxenous species that colonise voles in forest geobiocoenoses. It is a mountain element spread almost exclusively in the montane zone of the higher Carpathian Mountains. A. penicilliger prefers C. glareolus.

Megabothris turbidus (Rothschild, 1909) is a pleioxenous polysonal species with a broad host spectrum. This flea species prefers $C$. glareolus and A. flavicollis. It inhabits forest geobiocoenoses up to the supramontane zone, where it shares space and hosts with the congeneric species of $M$. rectangulatus. It is the second most represented species in our material.

Megabothris rectangulatus (Wahlgren, 1903) is a Boreo-Alpine species; a true alpine species which favors mountain vole species. In our material, it was obtained from the hosts $M$. tatricus and $C$. glareolus.

Nosopsyllus fasciatus (Bosc d'Antic, 1800) is a cosmopolitan parasite of synanthropic rodents that in mountainous areas occurs only in and around human habitats. It is a synanthropic, azonal flea species. It was found in our material on A. flavicollis and C. glareolus. 


\section{Host preference}

On the basis of the preference index in the conditions of the Belianske Tatras, there is a positive preference of $N$. fasciatus, $R$. integella, $M$. turbidus, $C$. agyrtes and $C$. bisoctodentatus to Apodemus flavicollis; A. nuperus, A. penicilliger, $C$. uncinatus, $P$. bidentata, $P$. silvatica, $M$. rectangulatus, $M$. turbidus, $C$. bisoctodentatus and $C$. agyrtes to Clethrionomys glareolus; $H$. orientalis and $C$. agyrtes to Microtus agrestis; $A$. arvicolae, $M$. rectangulatus, $P$. silvatica and $R$. integella to Microtus taricus; $D$. dasycnema and $P$. soricis to Neomys anomalus; P. soricis, $H$. orientalis and $D$. dasycnema to Neomys fodiens, to $S$. alpinus and to Sorex araneus; D. dasycnema and P. soricis to Sorex minutus (Table 4).

\section{Discussion}

Altitude gradients have the potential to be ideal for the long-term monitoring of organisms' responses to climate changes (Grytnes and MCCAIN, 2007; MCCAIN and GRYTNES, 2010; FISCHER et al., 2011). The largest number of fleas out of all of them captured from their hosts was observed in Clethrionomys glareolus, Apodemus flavicollis and Sorex araeus. These species are the commonest small mammals in the Western Carpathians and reflect glareolus-flavicollis communities covering forest geobiocoenoses from lowland to montane levels (DuDICH, 1992). Dudich (1992) comments on the gradual qualitative-cavitative rebuilding of the community running along the vertical gradient, whose relative density is decreasing particularly among herbivores while supramontane species diversity and balance are rising. Similarly, there is a change in the flea community structure found on small mammals with the elevation gradient. There has been no confirmation of the significant effect from the elevation gradient on small mammal fleas due to insufficient study about the fleas at individual sites within the monitored gradient. In total, 15 flea species from three families (Ceratophyllidae, Ctenophthalmidae and Hystrichopsyllidae) were collected from small mammal hosts. Based on the small mammals that had been captured at the Belianske Tatras (Zadné Med'odoly) between June and September 1987, Dudich (unpublished) reports two other species not confirmed by our research: Rhadinopsylla mesoides (Smit, 1957) and Amphipsylla sibirica (Jordan, 1932) (mountain, alpine species). BARTKOWSKA (1973) found 21 species of small mammal fleas in Poland's Tatra Mountain. (Moreover, she confirmed Archaeosylla erinacei, Hystrichopsylla talpae, Palaeopsylla steini, Monopsyllus sciurorum there). CYPRICH and KIEFER (1972) monitored nests of Microtus arvalis around the High Tatras. An analysis of 83 nests (50 of which were found to have fleas) confirmed the presence of 11 species (C. agyrtes, $C$. assimilis, C. uncinatus, $M$. turbidus, $M$. rectangulatus, A. penicilliger, A. rossica, H. talpae, R. integella casta, D. dasycnema, P. fallax). RosickÝ (1955) mentions the following species obtained from the fur of $M$. arvalis at the High Tatras: C. agyrtes, C. assimilis, D. dasycnema, P. fallax, P. bidentata, M. turbidus and A. rossica. Our research confirmed all of the flea species that had been reported with the exception of $A$. rossica. Besides the species we identified, CyPrich and ŠTIAVNICKÁ (2003) also mention records kept by Professor Mrciak (dating from 1967-69) that indicate the occurrence of Rhadinopsylla mesoides (confirmed by Dudich as well), Palaeopsylla similis similis and Palaeopsylla steini in the High Tatras and Belianske Tatras. Fleas on small terrestrial mammals at the Western Tatras were monitored between 1977 and 1982 by DuDich (1989), who confirmed the presence of 22 flea species (on 14 species of small mammals): Hystrichopsylla orientalis, Ctenophthalmus bisoctodentatus, C. agyrtes peusianus, C. congener, C. uncinatus, Doratopsylla dasycnema, Palaeopsylla soricis rosickyi, P. similis, P. kohauti steini, Rhadinopsylla pentacantha, $R$. isacantha, $R$. mesoides, $R$. integella, Peromyscopsylla bidentata, P. silvatica, Amphipsylla rossica, A. sibirica hetera, Amalaraeus penicilliger kratochvili, A. arvicolae, Megabothris turbidus, M. rectangulatus and Dasypsyllus gallinulae. The seasonal occurrence of fleas in the nests of Microtus arvalis was monitored by CYPRICH and KIEFER (1972), who found that most of the fleas were present in April and November. C. agyrtes was the only species that occurred throughout the year, prevailing also in summer nests. Specific vole species, such as C. assimilis and Amphipsylla rossica, also showed a high incidence of flea infestation during this period. On the other hand, C. uncinatus and $M$. turbidus were underrepresented. No occurrence of $M$. penicilliger and $D$. dasycnema were found in winter nests, while $R$. integella, a typical autumn and winter submontane and montan species, did appear. Winter flea species with limited occurrence during the year, mostly from late summer to winter, include species present in what had been collected from their host animals, namely $H$. orientalis, $R$. integella, $P$. bidentata and $A$. arvicolae (RosickÝ, 1957; Dudich, 1982, 1989).

\section{Faunistic and zoogeographical notes}

Small terrestrial mammal communities have a distinct flea synusia varying in time and space that is called the "small terrestrial mammal siphonaptera zone” (RosickÝ, 1950, 1957). It includes all the identified species, excluding Ctenophthalmus bisoctodentatus, which belongs to the siphonaptera range of mole (talpa) and Nosopsyllus fasciatus from the siphonaptera range of synanthropic rodents. The fauna (as well as the flora) of the Eastern Carpathians unfolds in the Belianske Tatras, at the area of contact of alpine and eastern Carpathian fauna (BARTKOwSKA, 1973), where she found a subspecies unknown to science (Rhadinopsylla mesoides skuratowiczi), three new Polish animal species (R. mesoides, Amphipsylla sibirica and Ischnopsyllus obscurus), three species and two subspecies completely new in the entire Tatra Mountain region (A. nuperus, I. obscurus, D. dasycnema cuspis and M. penicilliger 
Table 4. Flea to host preference index under conditions in the Belianske Tatras (2010-2014)

\begin{tabular}{|c|c|c|c|c|c|c|c|c|c|c|c|}
\hline & $A f l$ & $C g l$ & Mag & Mar & Msu & Mta & Nan & Nfo & Sal & Sar & Smi \\
\hline A. arvicolae & - & - & - & - & - & 168.46 & - & - & - & - & - \\
\hline A. penicilliger & 0.08 & 1.99 & 0.49 & - & - & - & - & - & 0.34 & - & - \\
\hline A. nuperus & - & 2.04 & - & - & - & - & - & - & - & - & - \\
\hline C. agyrtes & 1.22 & 1.42 & 2.25 & 0.43 & - & 0.12 & - & - & - & 0.07 & 0.15 \\
\hline C. bisoctodentatus & 1.23 & 1.53 & - & - & - & - & - & - & - & - & - \\
\hline C. uncinatus & 0.37 & 1.86 & - & - & - & - & - & - & - & 0.07 & - \\
\hline D. dasycnema & 0.22 & 0.07 & 0.67 & - & - & - & 4.01 & 1.60 & 11.33 & 4.87 & 2.19 \\
\hline H. orientalis & 0.52 & 0.91 & 7.77 & - & - & 0.63 & - & 2.07 & 5.48 & 1.43 & - \\
\hline M. rectangulatus & - & 1.81 & - & - & - & 3.29 & - & - & & - & - \\
\hline M. turbidus & 1.50 & 1.35 & 1.20 & 0.86 & - & 0.12 & 0.72 & - & - & 0.01 & 0.08 \\
\hline N. fasciatus & 3.52 & 0.58 & - & - & - & - & - & - & - & - & - \\
\hline P. soricis & 0.07 & 0.09 & - & - & 1.23 & - & 3.69 & 4.18 & 14.31 & 4.68 & 1.21 \\
\hline P. bidentata & 0.29 & 1.86 & - & - & - & 0.43 & - & - & - & - & 0.58 \\
\hline P. silvatica & - & 1.78 & - & - & - & 3.04 & - & - & - & 0.17 & - \\
\hline R. integella & 2.05 & 1.02 & - & - & - & 2.47 & - & - & - & - & - \\
\hline
\end{tabular}

1, neutral relation; <1, negative preference; >1, positive preference; Afl, Apodemus flavicollis; Cgl, Clethrionomys glareolus; Mag, Microtus agresti; Mar, Microtus arvalis; Msu, Microtus subterraneus; Mta, Microtus tatricus; Nan, Neomys anomalus; Nfo, Neomys fodiens; Sal, Sorex alpinus; Sar, Sorex araneus; Smi, Sorex minutus.

mustelae). The occurrence of the following flea species with mixed populations of western and eastern subspecies was documented in the Belianske Tatras: Ctenophthalmus agyrtes peusianus $\times$ C. agyrtes kleinschmidtianus, Doratopsylla dasycnema dasycnema $\times D$. dasycnema cuspis (respectively, both taxons are semispecies and hybridise in the clash of different areas), Palaeopsylla soricis rosickyi $\times$ P. soricis starki, Amalareus penicilliger kratochvili $\times$ A. penicilliger mustelae. In the observed area, the parapatric species Peromyscopsylla fallax alternate with $P$. silvatica, while Ctenophthalmus congener does the same with $C$. uncinatus and C. obtusus. Megabothris turbidus and $M$. rectangulatus alternate zonally, while Amphipsylla rossica alternates in the basin and $A$. sibirica in the supramontane and subalpine zone.

The zoogeography of the Tatra Mountains turned out to be very interesting, as they are a barrier in fleas dispersing eastward from the west and westward from the east. The Tatra Mountain fauna hosted by fleas reveals the most numerous connections with the eastern Carpathian. (Rhadinopsylla mesoides, Ctenophthalmus obtusus, Doratopsylla dasycnema cuspis, Amalaraeus penicilliger kratochvili) and somewhat less numerous connections with Alpine fauna (Atyphloceras nuperus, Megabothris rectangulatus). Zoogeographically, European (Ctenophthalmus agyrtes, Ctenophthalmus bisoctodentatus, Palaeopsylla soricis rosickyi, Amalareus penicilliger mustelae) and Eurosiberian (Hystrichopsylla orientalis, Doratopsylla d. dasycnema, Rhadinopsylla integella, Peromyscopsylla bidentata, Peromyscopsylla silvatica, Amalaraeus arvicolae, Megabothris turbidus) elements are the most numerous, while Alpine (Atyphloceras nuperus, Rhadinopsylla mesoides, Amphipsylla sibirica, Amalaraeus penicilliger kratochvili) and Boreoalpine (Megabothris rectangulatus) elements are rather poorly represented. The only Mediterranean element found is Doratopsylla dasycnema cuspis and Nosopsyllus fasciatus is a cosmopolitan species. The study is the first more comprehensive overview of the siphonapterofauna of small terrestrial mammals at the Belianske Tatras from a wider altitude gradient based on the multiannual stationary quadrate collection above the village of Tatranska Javorina. The occurrence of 15 flea species was found colonising small terrestrial mammals from the siphonaptera range of mall terrestrial mammals, encompassing the sifonaptera range of the mole (Talpa) and the siphonaptera range of synanthropic rodents. Winter species of fleas, occurring from late summer to winter, include $H$. orientalis, $R$. integella, P. bidentata and A. arvicolae. Mountain species favouring higher elevations include $A$. nuperus, $C$. uncinatus, $A$. arvicolae, $A$. penicilliger and $M$. rectangulatus.

Note: Publications by Baláž and Augustiničová (2012) and Augustiničoví and BALÁž (2014) mentioned by mistake the presence of Ctenophthalmus congener, Ctenophthalmus solutus, Ctenophthalmus wagneri and Megabothris walkeri in the Belianske Tatras.

\section{Acknowledgements}

We express our sincere thanks to Michal Ambros, Gabriela Augustiničová, Titusz Bugya, Robert Herczeg, Imrich Jakab, Martin Lukáň, Roman Slobodník, Michal Ševčík, Tomáš Veselovský and Sylvia Zwolak, who helped with trapping the small mammals. We thank Richard Budd 
for linguistic proofreading of the manuscript. This study was conducted with the financial support of the Scientific Grant Agency VEGA, Grant No 1/0608/16. The research was carried out under the authority of the Ministry of the Environment of the Slovak Republic, stated in Decision No 6829/2010-2.1.1/jam. and 5451/2012-2.2. We would also like to thank Prof Alexander Dudich for his very critical comments on siphonaptera issues.

\section{References}

Augustiničová, G., BALÁž, I., 2014. Sezónna dynamika synúzií bĺch (Siphonaptera) drobných zemných cicavcov v lesnom ekosystéme Tatier [Seasonal dynamics of flea synusiae (Siphonaptera) of small mammals in forest ecosystem of Tatra Mts.]. In Bryja, J., DrozD, P. (eds). Zoologické dny. Sbornik abstrakti̊ z konference 6. - 7. února 2014. Brno: Ústav biologie obratlovců AV ČR, p. 25.

Baláž, I., Augustiničová, G., 2012. Synúzie blch (Siphonaptera) drobných zemných cicavcov (Eulipotyphla, Rodentia) vybraných lokalít Belianskych a Vysokých Tatier [Flea synusiae (Siphonaptera) of small mammals (Eulipotyphla, Rodentia) in selected sites of Belianske and Vysoké Tatra Mts.]. In BryjA, J., AlBrechtová, J., TKADLEC, E. (eds.). Zoologické dny Olomouc 2012. Sbornik abstraktů z konference 9. - 10. února 2012. Brno: Ústav biologie obratlovců AV ČR, p. 242.

BartkowsKa, K., 1973. Siphonaptera Tatr Polskich [Siphonaptera of Polish Tatra Mts.]. Fragmenta Faunistica 19, 2 : 227-283.

Brinck-Lindroth, G., Smit, F.G.A.M., 2007. The fleas (Siphonaptera) of Fennoscandia and Denmark. Fauna Entomologica Scandinavica, 4. Leiden, Boston: Brill. 185 p.

Bush, A.O., Lafferty, K.D., Lotz, J.M., Shostak, A.W., 1997. Parasitology meets ecology on its own terms: Margolis et al. revisited. Journal of Parasitology, 83: 575583.

CyPrich, D., Kiefer, M., 1972. Príspevok k poznaniu aphanipterofauny hniezd Microtusarvalis (Pall. 1778) v oblasti Vysokých Tatier [Contribution to aphanipterofauna knowledge of nests of Microtus arvalis (Pall. 1778) in High Tatra Mts.]. Acta Facultatis Rerum Naturalium Universitatis Comenianae. Zoologia, 17: 55-62.

Cyprich, D., Štiavnická, L., 2003. Blchy (Siphonoptera) z hniezd cicavcov (Mammalia) z pozostalosti prof. Milana Mrciaka - Vysoké a Belianske Tatry [Fleas (Siphonaptera) from nests of mammals (Mammalia) from the estate of prof. Milan Mrciak - High and Belianske Tatra Mts.]. Folia Faunistica Slovaca, 8: 53-55.

Dudich, A., 1982. Anotovaný prehl'ad ektoparazitov drobných zemných cicavcov (Insectivora, Rodentia) Oravy. I. Siphonaptera [Annotated overview of ectoparasites of small mammals (Insectivora, Rodentia) in Orava]. Oravské múzeum - spravodaj, 2/82. Dolný Kubín: Oravské múzeum, p. 38-53.

Dudich, A., 1989. Príspevok k poznaniu ektoparazitov drob- ných zemných cicavcov Západných Tatier 1. Siphonaptera [Contribution to ectoparasites of small mammals knowledge of Western Tatra Mts. 1. Siphonaptera]. In Stredné Slovensko 8. Prírodné Vedy. Zborník Stredoslovenského múzea v Banskej Bystrici. Martin: Osveta, p. 185-205.

Dudich, A., 1992. Stav poznania štruktúry spoločenstiev drobných cicavcov a ich ektoparazitov lesných geobiocenóz Západných Karpát [State of knowledge of the structure of small mammal communities and their ectoparasites of forest geobiocoenosis of the Western Carpathians]. In Ekologický a ekofyziologický výskum v lesných ekosystémoch. Celoštátna vedecká konferencia. Zvolen: Lesnícky výskumný ústav, p. 180-182.

DuDICH, A., 1995. Synekologická štúdia ektoparazitov drobných cicavcov smrekových lesov v oblasti Stredných Bes$k \dot{y} d$ [Synecological study of small mammals ectoparasites of spruce forests in Stredné Beskydy Mts. (West Carpathians)]. Vedecké a pedagogické aktuality, 8/94. Zvolen: Technická univerzita vo Zvolene. 47 p.

Dudich, A., 1996. Sympatria a parapatria druhov rodu Peromyscopsylla Fox, 1939 (Siphonaptera: Leptopsyllidae) v Západných Karpatoch. 1. Rozšírenie Peromyscopsylla bidentata (Kolenati) na území Slovenskej republiky [Sympatry and parapatry in species of Peromyscopsylla Fox, 1939 (Siphonaptera: Leptopsyllidae) in West Carpatians. 1. Distribution of Peromyscopsylla bidentata (Kolenati) on the territory of Slovak Republic]. Acta Facultatis Ecologiae Zvolen, 3: 77-91.

Dudich, A., 1997. Sympatria a parapatria druhov rodu Peromyscopsylla Fox, 1939 (Siphonaptera: Leptopsyllidae) v Západných Karpatoch. 2. Rozšírenie Peromyscopsylla silvatica (Meinert) na území Slovenskej republiky [Sympatry and parapatry in species of Peromyscopsylla Fox, 1939 (Siphonaptera: Leptopsyllidae) in West Carpatians. 2. Distribution of Peromyscopsylla silvatica (Meinert) on the territory of Slovak Republic]. Acta Facultatis Ecologiae Zvolen, 4: 75-85.

Dudich, A., 2004. Sympatria a parapatria druhov podrodu Euctenophthalmus Wagner, 1940 (Siphonaptera: Ctenophthalmidae) v Západných Karpatoch. 4. Rozšírenie Ctenophthalmus (Euctenophthalmus) uncinatus (Wagner, 1898) v Slovenskej republike [Sympatry and parapatry in species of Euctenophthalmus Wagner, 1940 (Siphonaptera: Ctenophthalmidae) in West Carpathians. 4. Distribution of Ctenophthalmus (Euctenophthalmus) uncinatus (Wagner, 1898) in Slovak Republic]. Acta Facultatis Ecologiae Zvolen, 12: 73-87.

Dudich, A., MatoušEK, B., 1985. Blchy (Insecta, Siphonaptera) zo zbierok Slovenského národného múzea v Bratislave [Fleas (Insecta, Siphonaptera) from the collections of the Slovak National Museum in Bratislava]. Zbornik Slovenského národného múzea. Prírodné Vedy, 31: 81104.

Fischer, A., BlaschKe, M., BäSSler, C., 2011. Altitudinal gradients in biodiversity research: the state of the art and future perspectives under climate change aspects. Waldökologie, Landschaftsforschung und Naturschutz, 11: 35-47.

Grytnes, J.A., McCaIn, C.M., 2007. Elevational trends in biodiversity. In Encyclopedia of biodiversity. Amsterdam: 
Elsevier, p. 1-8.

JORDAN, K., 1932. Siphonaptera collected by Herr Georg Stein in the High Tatra. Novitatis Zoologiae, 38: 261-263.

JuRík, M., 1955. Príspevok k poznaniu bĺch (Aphaniptera) ČSR [Contribution to fleas' knowledge (Aphaniptera) of Czechoslovakia]. Acta Universitatis Agriculturae et Silviculturae Brno, 2: 175-180.

JuRík, M., 1968. Fleas of the Mole Talpa europaea L. in Czechoslovakia (Aphaniptera). Acta Entomologica et Bohemoslovaca, 65 (1): 67-75.

KanKA, R., 2008. Lesy Belianskych Tatier [Forests of Belianske Tatra Mts.]. Bratislava: Veda. 250 p.

Krasnov, B.R., 2008. Functional and evolutionary ecology of fleas: a model for ecological parasitology. Cambridge: Cambridge University Press. 593 p.

Margolis, L., Esch, G.W., Holmes, J.C., Kuris, A.M., SCHAD, G.A., 1982. The use of ecological terms in parasitology (report of an ad hoc committee of the American Society of Parasitologists). Journal of Parasitology, 68: 131-133.

MCCAIn, C.M., GrYTNES, J.A., 2010. Elevational gradients in species richness. In Encyclopedia of life sciences. Chicester: Wiley, p. 1-10.

MidRIAK, R., 1983. Morfogenéza povrchu vysokých pohori: morfologická štúdia s osobitným zretelom na deštrukciu pôdy v Západných Karpatoch [Morphogenesis of high mountain surface: morphological study with special regard to soil destruction in Western Carpathians]. Bratislava: Veda. 516 p.

Mrciak, M., RosickÝ, B., 1970. Ekologické štúdie o nidikolnej faune drobných cicavcov vo Vysokých Tatrách [Ecological studies about nidicolous fauna of small mammals in High Tatra Mts.]. In MARČEK, A. (ed.). Národné bohatstvo - bohatstvo civilizácie. Zborník referátov $z$ medzinárodného sympózia konaného $v$ dňoch 8. - 13. septembra v Tatranskej Lomnici z príležitosti 20. výročia uzákonenia Tatranského národného parku. Bratislava: Príroda, p. 360-383.

Mrciak, M., RosickÝ, B., 1975. Some features of the zoogeography of high altitude parasites of birds and mammals on the example of the High Tatra Mountains (Slovakia). Biológia, Bratislava, 38 (8): 589-597.
RosickÝ, B., 1950. Predbežný katalóg bĺch (Aphaniptera) $\mathrm{z}$ územia Slovenska [Preliminary catalog of fleas (Aphaniptera) from the territory of Slovakia]. Prírodovedný sbornik Bratislava, 5: 155-171.

RosickÝ, B., 1952. 1. dodatek k prodromu blech (Aphaniptera) ČSR [The first supplement to prodrom of fleas (Aphaniptera) in the Czechoslovak Republic]. Sbornik Entomologického Oddělení Národního Musea v Prase, 28: 5-18.

RosickÝ, B., 1955. Aphanipterofauna Vysokých Tater s poznámkami o výškovém rozvrstvení blech $\mathrm{v}$ tomto horstvu [Aphanipterofauna of High Tatra Mts. with comments about altitude stratification in this mountain range]. Zoologické a Entomologické Listy, 4: 365-383.

RosickÝ, B., 1957. Blechy-Aphaniptera [Fleas - Aphaniptera]. Fauna ČSR, sv. 10. Praha: Československá akademie věd. $439 \mathrm{p}$.

RosickÝ, B., 1974. Aphaniptera. In Zborník prác o Tatranskom národnom parku. 16. Treatises concernig the Tatra National Park. 16. Martin: Osveta, p. 85-191.

Rosický, B., MrCiAK, M., 1970. Zoogeografia parazitov Vysokých Tatier [Zoogeography of parasites in High Tatra Mts.]. In MARČEK, A. (ed.). Národné bohatstvo - bohatstvo civilizácie. Zborník referátov z medzinárodného sympózia konaného $v$ dňoch 8. - 13. septembra v Tatranskej Lomnici z príležitosti 20. výročia uzákonenia Tatranského národného parku. Bratislava: Príroda, p. 445-459.

Schwerdtfeger, F., 1975. Synökologie. Hamburg: Paul Parey. $451 \mathrm{p}$.

Skuratowicz, W., 1967. Pchty - Siphonaptera [Fleas - Siphonaptera]. Klucze do oznaczania owadów Polski, 29. Warszawa: Państwowe Wydawnictwo Naukowe Warszawa. $141 \mathrm{p}$.

Stanová, V., Valachovič, M. (eds), 2002. Katálog biotopov Slovenska [Catalogue of habitats in Slovakia]. Bratislava: Daphne - Inštitút aplikovanej ekológie. 225 p.

TRPIŠ, M., 1994. Host-parasite relationships between fleas (Siphonaptera) and small mammals of theTatra Mts. in Slovakia. Bulletin of the Society for Vector Ecology, 19 (1): 13-17. 